\title{
Nattarbeid påvirker ikke menstruasjonen
}

\section{A arbeide på natten påvirker verken den psykiske helsen eller menstruasjonen negativt. Derimot finner vi en sammenheng mellom nattarbeid og økt BMl.}

\section{FORFATTERE}

Siri Waage

Senterkoordinator og postdoktor

Universitetet i Bergen og Haukeland universitetssykehus

Eiunn Thun

Psykolog og forsker,

Iselin Reknes

Ph.d.-kandidat

Universitetet i Bergen

Bente Elisabeth Moen

Lege og professor

Universitetet i Bergen

Nils Magerøy

Lege og enhetsleder,

Ståle Pallesen

Seniorforsker og professor

Universitetet i Bergen og Haukeland universitetssykehus

Bjørn Bjorvatn

Leder og professor

Nasjonal kompetansetjeneste for søvnsykdommer, Haukeland universitetssykehus og Universitetet i Bergen

\section{HOVEDBUDSKAP}

Over flere år har den fysiske og psykiske helsen til sykepleiere som jobber turnus, blitt målt. Verken psykisk helse eller menstruasjonen påvirkes negativt, men mange sykepleiere som arbeider på natten, har høy BMI. 
Vi ønsker at norske sykepleiere skal få kunnskap om resultatene fra unders $\varnothing$ kelsen. I denne artikkelen gir vi derfor en kortfattet oppsummering av de artiklene som ble publisert i løpet av 2015, totalt sju artikler (3-9). Artiklene omhandlet alt fra sykefravær til fysisk og psykisk helse, søvnforstyrrelser og reproduktiv helse.

\section{OM UNDERS $\varnothing K E L S E N$}

Unders $\emptyset$ kelsen fokuserer hovedsakelig på søvn og helse samt arbeidsmiljøtemaer som mobbing og jobbtilfredshet. Også arbeidstid og sammenheng med reproduktiv helse (menstruasjonssyklus, graviditet og spontanabort) har vært viktige temaer. Hovedmålet er å se på hvordan sykepleieres helse utvikler seg over tid, spesielt relatert til ulike typer arbeidstid og turnusarbeid. I tillegg har vi tatt blodprøver for genanalyser av et underutvalg av sykepleierne, mens et annet underutvalg har fylt ut menstruasjonsdagbok.

Vi har også innhentet tillatelse til å kunne kople svar til ulike registre som FD-Trygd (en forløpsdatabase der trygdestatus og trygdeforhold utgjør en stor del av dataene) og fødselsregistret. I en slik langvarig undersøkelse er det en stor styrke å kunne kople til slike registre og undersøke utvikling over tid basert på flere måletidspunkter.

Vinteren 2008/2009 sendte vi ut det første spørreskjemaet til 6000 sykepleiere i Norge. Fra runde nummer to, sendt ut i 2010, har SUSSH årlig sendt ut spørreskjemaer til alle som svarte på den første undersøkelsen, det vil si om lag 2900 norske sykepleiere. Unders $\emptyset$ kelsen har $\mathrm{i}$ alle oppfølgingsrundene hatt en høy svarprosent, mellom 65 prosent og 80 prosent, noe som vi er svært forn øyde med. I 2015 gjennomførte vi runde nummer sju, med en svarprosent på 68 prosent. Spørreskjemaet som ble sendt ut i 2015, omhandlet hovedsakelig fysisk og psykisk helse, arbeidsmiljø og reproduksjon.

Spørreskjemaet varierer fra år til år. Mange spørsmål gjentas årlig, mens andre spørsmål gjentas noe sjeldnere. De fleste av spørsmålene er hentet fra standardiserte spørreskjemaer som gjør det mulig å sammenlikne resultatene med liknende studier fra andre land og andre populasjoner.

\section{SKIFTARBEIDSTOLERANSE}

Skiftarbeid kan føre til mange negative helsekonsekvenser. Noen tåler imidlertid godt å jobbe skift eller turnus. Evnen til å tilpasse seg skift- og turnusarbeid uten de negative konsekvensene som ofte er forbundet med slik arbeidstid, omtales som «skiftarbeidstoleranse». Ulike personlighetstrekk, som blant annet det å være et morgenmenneske, være robust og fleksibel (ha evne til å arbeide og sove på varierende tidspunkt av døgnet), er faktorer knyttet til høy skiftarbeidstoleranse $(1,2)$.

Begrepet «skiftarbeidstoleranse» har imidlertid vært diskutert, både når det gjelder hvordan begrepet skal defineres, og ikke minst hvordan skiftarbeidstoleranse skal måles. Noe av kritikken har vært at begrepet ikke er bredt nok til å beskrive hvilke problemer skiftarbeidere opplever - at psykososiale og sosiale problemer ikke er inkludert i definisjonen.

For å bidra til en mer presis forståelse av dette begrepet, publiserte vi en artikkel i 2015 der målet var å identifisere ytterligere karakteristika ved individuelle forskjeller knyttet til skiftarbeidstoleranse (3). Resultatene viste at særlig to faktorer synes å være av betydning for skiftarbeidstoleranse. Den første er velvære, som var relatert til lav grad av søvnvansker og tretthet, og rapportering av god mental helse. Den andre faktoren er fysisk helse, der god fysisk helse var positivt relatert til skiftarbeidstoleranse. Artikkelen konkluderer med at en ny definisjon av skiftarbeidstoleranse bør inkludere et bredt spekter av helserelaterte variabler.

\section{REPRODUKTIV HELSE}


Det er rapportert at nattarbeid kan føre til menstruasjonsforstyrrelser, for eksempel i form av for korte eller for lange menstruasjonssykluser. Uregelmessig menstruasjon kan være en indikator på nedsatt fruktbarhet. Mekanismene bak endringer i menstruasjonssyklusen relatert til natt- eller turnusarbeid, er uklare. Hormonelle forstyrrelser på grunn av endringer i døgnrytmen kan være en mulig forklaring. Det har i tillegg blitt foreslått at søvnforstyrrelser, som insomni og lite $s \varnothing \mathrm{vn}$, kan være relatert til endringer i menstruasjonssyklus.

I en studie fra SUSSH som ble publisert i 2015, ble det unders $\varnothing \mathrm{kt}$ hvorvidt nattarbeid var assosiert til lengden og regelmessigheten av menstruasjonssyklusen. Vi unders $\varnothing$ kte også om det var en sammenheng mellom det som beskrives som «skiftarbeidslidelse», og menstruasjonssyklus (4). Skiftarbeidslidelse er definert som det å ha søvnproblemer og uttalt tretthet knyttet til arbeidstidsordninger der man arbeider på tidspunkter man normalt ville ha sovet.

\section{«Hovedmålet er å se på hvordan sykepleieres helse utvikler seg over tid.»}

Vi undersøkte 766 kvinnelige sykepleiere fra SUSSH som var yngre enn 50 år, ikke gravide, ikke brukte hormonpiller eller spiral, og som ikke hadde nådd overgangsalder. Disse sykepleierne svarte på spørsmål om nattarbeid og menstruasjonssyklus. 15 prosent rapporterte å ha uregelmessige menstruasjoner, og 39 prosent fylte kriteriene for skiftarbeidslidelse. Vi fant ingen sammenheng mellom nattarbeid og uregelmessige menstruasjoner blant disse sykepleierne. Vi fant heller ingen sammenhenger mellom sykluslengden eller varighet av blødningsperioden og nattarbeid, og heller ikke noen sammenheng mellom skiftarbeidslidelse og menstruasjonssyklus. At vi ikke fant slike sammenhenger, kan muligens forklares med at våre sykepleiere har bedre turnusordninger og arbeidsforhold enn dem som er beskrevet i andre studier.

\section{FYSISK HELSE}

Skiftarbeid, og da spesielt nattarbeid, er assosiert med flere negative helseeffekter når vi sammenlikner med dagarbeidere. Det er også rapportert økt forekomst av kardiovaskulære risikofaktorer som for eksempel røyking og vektøkning blant skiftarbeidere og nattarbeidere, som igjen kan føre til økt risiko for kardiovaskulær sykdom. Vi brukte data fra første runde i SUSSH, som inkluderte i overkant av 2000 sykepleiere (5). Ulike demografiske faktorer og livsstilsfaktorer som kroppsmasseindeks (BMI), røyk- og alkoholvaner, koffeinbruk og fysisk aktivitet ble undersøkt opp mot antall netter de arbeidet i løpet av det siste året. Vi fant en signifikant positiv sammenheng mellom nattarbeid og høy BMl og fedme. Vi vet ikke om dette skyldes nattarbeidet i seg selv eller uheldig kosthold og lite mosjon. Arbeidstakere med høy andel av nattarbeid kan dermed ha behov for tett oppfølging og hyppige helsesjekker på grunn av $\emptyset$ kt risiko for slike uønskete helseeffekter.

\section{PSYKISK HELSE}

Skiftarbeid er også rapportert å ha en negativ effekt på psykisk helse, slik som for eksempel angst og depresjon. Vi gjennomførte derfor en studie hvor målet var å belyse potensielle effekter av både skiftordninger og arbeidsmiljø på ulike psykiske plager (6). I alt 1582 sykepleiere som svarte på de to første rundene i SUSSH, var med i disse analysene. Resultatene viste at det ikke var noen sammenheng mellom dagarbeid, nattarbeid eller roterende turnusarbeid og angst eller depresjon. å spille en rolle for rapportering av angst. Opplevelse av jobbkrav syntes imidlertid å spille en 
rolle for symptomer på depresjon ved ett års oppfølging. Oppsummert fant vi altså ikke noen negative psykiske helseeffekter av å jobbe natt- eller turnusarbeid. Siden det sannsynligvis tar litt tid før arbeidsforhold påvirker helsen, kan undersøkelser med lengre tidsspenn og med flere måletidspunkter gi ytterligere kunnskap om mulige sammenhenger mellom arbeidsmiljøfaktorer og psykiske plager.

\section{SYKEFRAVAR}

Selvrapportert helse er forbundet med sykefravær. I 2015 undersøkte vi om et enkelt spørsmål om selvrapportert helse var like sterkt forbundet med fremtidig sykefravær som et standardisert flerleddet spørreskjema (SF-12) på selvrapportert helse (7). Vi brukte data fra to runder i SUSSH, og analysene inkluderte til sammen 1253 sykepleiere. Funnene viste at det flerleddete spørreskjemaet predikerte høyt sykefravær mer nøyaktig enn enkeltspørsmålet om selvrapportert helse. I tillegg predikerte det flerleddete skjemaet et sykefravær som var mer stabilt over tid. Konklusjonen er likevel at et enkelt spørsmål om selvrapportert helse kan være godt nok som mål for å identifisere hvorvidt ansatte har høy risiko for fremtidig sykefravær.

\section{«Søvnforstyrrelser er blant de hyppigst rapporterte plagene.»}

Langtidssykmelding har vært brukt som et mål på helsetilstand og funksjonsnivå, og det finnes flere validerte spørreskjemaer for å måle fysisk, mental og sosial helse. Vi undersøkte om en kortversjon av SF-12, et mye brukt spørreskjema om helse, kan predikere langtidssykefravær som skyldes psykiske helseplager, muskelskjelettplager eller andre somatiske plager (8). Vi brukte data fra to års oppfølging fra SUSSH i analysene, og resultatene viste at ulike dimensjoner i SF-12 kan brukes til å forutsi langtidssykefravær relatert til mentale plager, muskelskjelettplager eller andre somatiske plager. St $\varnothing$ rre studier på ulike populasjoner er likevel nødvendig for å undersøke om et slikt spørreskjema kan brukes for å kunne screene for risiko for fremtidig langtidssykefravær blant arbeidstakere.

\section{SøVNSYKDOMMER}

Søvn har vært et viktig tema i SUSSH, da søvnforstyrrelser er blant de hyppigst rapporterte plagene relatert til det å jobbe utenom ordinær dagtid, og da spesielt for nattarbeid. En av de seks hoveddiagnosegruppene innen søvnsykdommer er parasomnier, som er en samlebetegnelse på uønskete motoriske fenomener eller opplevelser som skjer under innsovning, i løpet av søvnperioden eller i forbindelse med oppvåkning fra søvn. Det er vanlig å dele parasomniene inn i tre hovedgrupper:

- forstyrrelser knyttet til den dype søvnen, slik som forvirringsoppvåkning, nattskrekkanfall og det å gå i søvne

- forstyrrelser knyttet til Rapid Eye Movement (REM)-søvn, slik som mareritt

- andre parasomnier som ikke er knyttet til spesielle $s \varnothing v n s t a d i e r$

Vi unders $\varnothing$ kte forekomsten av parasomnier blant i overkant av 2000 sykepleiere som svarte i første og fjerde runde (9). Resultatene viste at de sykepleierne som jobbet to-skift (dag og kveld) og sykepleierne som jobbet tre-skift (dag, kveld og natt), hadde økt risiko for forvirringsoppvåkning sammenliknet med sykepleiere som bare arbeider på dagtid. Sykepleiere som arbeidet to- og tre-skiftturnus, hadde også økt risiko for mareritt. Grunnen kan være døgnrytmeforskyvning og søvnmangel forårsaket av slike skiftordninger. De andre parasomniene var ikke assosiert med arbeidstid, og nattarbeid alene var ikke forbundet med $\emptyset \mathrm{kt}$ forekomst av parasomnier. 


\section{VEIEN VIDERE}

Det har stor nytteverdi å kunne følge en gruppe arbeidstakere over lengre tid. Gjennom SUSSH får vi viktig informasjon om sykepleieres helse. Vi ser også hvordan helsen utvikler seg i sammenheng med arbeidstidsordninger, individuelle forskjeller og personlighetstrekk samt andre forhold ved arbeidsmiljøet. Det er viktig med kunnskap om hvilke typer helseproblemer sykepleierne opplever, og hva som kan beskytte mot slike problemer for å kunne iverksette tiltak som kommer både sykepleiere og samfunnet for $\emptyset$ vrig til nytte.

Takk til sykepleierne som deltar i SUSSH. Takk også til NSF for støtte og økonomisk bidrag.

\section{REFERANSER}

1. Saksvik-Lehouillier I, Bjorvatn B, Hetland H, Sandal GM, Moen BE, Magerøy N, Harvey $A$, Costa G, Pallesen S. Personality factors predicting changes in shift work tolerance: A longitudinal study among nurses working rotating shifts. Work and Stress

2012;26(2):143-60.

2. Saksvik-Lehouillier I, Bjorvatn B, Hetland H, Sandal GM, Moen BE, Magerøy N, Åkerstedt T, Pallesen $\mathrm{S}$. Individual, situational and lifestyle factors related to shift work tolerance among nurses who are new to and experienced in night work. Journal of Advanced Nursing 2013;69(5):1136-46.

3. Saksvik-Lehouillier, I, Pallesen, S, Bjorvatn, B, Magerøy, N, Folkard, S. Towards more comprehensive definition of shift work tolerance. Industrial Health 2015;5;53(1):69-77.

4. Moen BE, Baste V, Morken T, Alsaker K, Pallesen S, Bjorvatn B. Menstrual characteristics and night work among nurses. Industrial Health 2015;53(4):354-60.

5. Buchvold H, Pallesen S, Øyane N, Bjorvatn B. Night work among nurses. Effects on $\mathrm{BMI}$, alcohol consumption, smoking, caffeine consumption, and exercise habits. A cross sectional study. BMC Public Health 2015;15:1112.

6. Berthelsen M, Pallesen S, Magerøy N, Tyssen R, Bjorvatn B, Moen BE, Knardahl S. Effects of psychological and social factors in shiftwork on symptoms of anxiety and depression in nurses - A 1-year follow-up. Journal of Occupational and Environmental Medicine 2015;57(10):1127-37.

7. Roelen CAM, Heymans MW, Twisk JWR, Laaksonen M, Pallesen S, Magerøy N, Moen $\mathrm{BE}$, Bjorvatn $\mathrm{B}$. Health measures in prediction models for high sickness absence: single item self-rated health versus multi-item SF-12. European Journal of Public Health

2015;25:668-72.

8. Roelen CAM, Heymans MW, Thun E, Reknes I, Laaksonen M, Magerøy N, Twisk JWR, Bjorvatn B, Pallesen S, Moen BE. Predictive value of the SF-12 for sickness absence due to mental, musculoskeletal, and other somatic sickness disorders. Journal of Occupational and Environmental Medicine 2015;57(10):1113-8.

9. Bjorvatn B, Magerøy N, Moen BE, Pallesen S, Waage S. Parasomnias are more frequent in shift workers than in day workers. Chronobiology International 2015;32(10):1352-8. 